\title{
Customer Participation in Service Specification and Delivery
}

Dr. Dianne S. P. Cermak, Marketing, Northeastern University

Dr. Karen Maru File, Marketing, University of Connecticut

Dr. Russ Alan Prince, Marketing, Prince \& Associates

\begin{abstract}
The fact that customers participate in the specification and delivery of the services they seek represents an important potential point of potential leverage for services providers as the nature and intensity of customer participation is within their ability to manage. Important questions, however, need to be raised and resolved. Does increased customer participation result in higher perceptions of quality and satisfaction or in greater repurchase? Are relationships between participation and repurchase affected by the type of service being provided or the length of the prior relationship? This paper traces the antecedents of participation in the services marketing literature, outlines points of distinction between participation and the related construct of involvement, and employs empirical evidence drawn from two professional service settings to address the research questions. Results confirm that participation is strongly associated with repurchase and referrals in some service settings, and a research agenda is proposed.
\end{abstract}

\section{Introduction}

The development over the last decade of services marketing theory prompts an exploration of the role of customer participation in service-based (rather than goods- based) transactions. It is at the purchase stage itself that services are most sharply distinct from goods in that, unlike goods, services are simultaneously created as they are consumed. This simultaneity of production and demand means that the buyer of the service participates in the specification and delivery of the service as it is being performed (Zeithaml, 1981). Although this aspect of services has wide acceptance in the theoretical literature, to date there has been no empirical test of the proposition that customer participation affects repurchase or referrals (Czepiel, 1990), nor have the effects of customer participation on perceptions of quality and satisfaction been empirically explored across service settings or among customers with varying degrees of experience with the service provider. Thus, the objective of this paper is to provide an empirical exploration of the relationship between customer participation and perceptions of quality and satisfaction as well as intentions to repurchase and refer under varying conditions of buyer experience and service settings. Results will enable an evaluation of the usefulness of participation as a construct both to evolving services marketing theory and to practitioners.

\section{Participation}

In contrast to other areas in the services marketing literature, notably the area of service quality, the role of participation is just beginning to receive attention. To date, participation has been shown to be related to increased customer satisfaction (Bateson, 1985; Cermak, File \& Prince, 1991; Mills \& Morris, 1986; Zeithaml 1981). In addition, customer participation in services specification and delivery has now been shown to provide a number of significant benefits to services providers, among them improved provider economies (Chase 1978), and enhanced backward information flow (Kelley, Connelly \& Skinner, 1990; Lovelock \& Young, 1979; Mills \& Moburg, 1982). As noted, however, there has been no empirical exploration of the relationship between customer participation and repurchase or referrals (Czepiel, 1990), nor is there any data bearing on questions of variation across different types of services or different types of relationships with providers.

\section{Participation and Involvement}

Before exploring participation, commonalities and distinctions with the construct of involvement need to be drawn. Participation refers to the customer behaviors related to specification and delivery of a service, while involvement has traditionally referred to the personal relevance or importance a product has for a consumer (Day, 1970; Greenwald \& Leavitt, 1985). Since participation is a behavior which may reflect a state of involvement, it is relevant to review the involvement literature 
for behaviors that on closer examination may be better classified as participation. As it turns out upon review, some of the many involvement scales that have been developed (Bloch, 1981; Higie \& Feick, 1989; Lastovicka \& Gardner, 1979: Laurent \& Kapferer, 1985; Slama \& Tashchian, 1985; Traylor \& Joseph, 1984; Zaichkowsky, 1985b) measure involvement, in part, as a behavior. For example, Slama and Tashchian's (1985) "Purchasing Involvement Scale" includes allusions to behaviors (e.g. "I often take advantage of coupon offers in newspapers"). Furthermore, the operationalization of the involvement construct sometimes incorporates a variable such as "attention" which, itself, frequently has behavioral concomitants (Richins \& Bloch, 1991; Mitchell, 1979).

In addition, involvement with a product category has been found to be associated with a variety of behaviors such as increased readership of periodicals, greater attention paid to related advertising, higher levels of product-related consultation with others, participation in the purchasing sequences of others, and greater levels of product usage (Higie \& Feick, 1989). This expression of involvement through behaviors has prompted some to suggest that involvement can be measured in terms of such response patterns (Ray 1973, Batra and Ray 1983). In their study of purchase and consumption of prerecorded music for example, Pucely, Mizerski and Perrewe (1988) conceptually and empirically distinguish what they call "behavioral involvement" (e.g., hours spent listening to audio media, frequency of concert attendance) from other attitudinal forms of involvement and in so doing approach measuring the construct we have been referring to as participation.

However, a strong case can be made for maintaining a rigorous boundary between attitudes (e.g. involvement) and behaviors (e.g. participation) in theory development and construct measurement. A significant body of research and theory from social psychology speaks to the need for this distinction. A theory of the mutual causal impact of attitudes and behaviors now typifies the field (Bentler \& Speckart, 1981; Kelman, 1974; Fazio and Zanna, 1981) supplanting early models of the predictive effect of attitudes on behaviors (Allport, 1935; McGuire, 1976; Wicker, 1969) and those of the effect of behaviors on attitudes (Bandura, 1976; Festinger, 1957). Although the debate does continue over causal sequencing and feedback effects, there is no debate within the field over the need to maintain the distinction between attitudes and behaviors in theory development and construct measurement. On this basis, as well as that of services marketing theory, the argument can be made for separating attitudinal and behavioral aspects of potentially related or overlapping constructs and creating clarifying nomenclature. On this basis, it appears appropriate to reserve involvement to refer to customer attitudes or states and to use participation to denote behaviors related to specification and use of a service. In so doing, participation subsumes relevant aspects of behavioral involvement.

\section{Development of Hypotheses on the Role of Participation}

Because of the points of overlap between participation and involvement, it is useful to look to the involvement literature for specific hypotheses on the role participation may play in buyer behavior processes. In the long (Sherif \& Cantril, 1947) and sizable literature on the topic, involvement has frequently been shown to affect pre-purchase processes (Clarke \& Belk, 1979), an aspect of involvement not relevant to a consideration of participation at the point of purchase. More to the point, involvement has also been shown to be a significant factor in post-purchase customer behaviors, among them attitude formation (Petty, Cacioppo \& Schumann, 1983), repurchase (Zaichkowsky, 1985a; Ram \& Jung, 1989), referrals (Richins \& Root-Shaffer, 1988), and related behaviors (Bloch, 1981; Slama \& Tashchian, 1985). This line of evidence leads to the question of whether participation can also be established as an important determinant of attitudes of satisfaction and quality and to behaviors of repurchase and referral within the domain of services marketing.

One of the reasons for the persistence of the involvement construct is that it involvement also has been shown to be relevant in understanding buyer behaviors across categories of goods as diverse as beer (Tyebjee, 1979), tennis products (Celsi \& Olson, 1988), soft drinks (Beatty, Kahle \& Homer, 1988), automobiles (Bloch, 1981) and jeans, laundry detergent, and color TV (Zaichkowsky, 1985b). For participation to be established, its utility will also need to be established across a wide array of services.

In addition, involvement has also been shown to vary under certain conditions having to do with aspects of the relationship between customer and product such as situational and enduring involvement (Houston \& Rothschild, 1978; Bloch, 1981; Bloch, 1982; Bloch \& Richins, 1983; Richins \& Bloch, 1986), and resulting high and low levels of involvement (Engel and Blackwell, 1982). On this basis, participation may be expected to vary, like involvement, by the relative experience of the customer with the product. For example, service customers might participate more extensively in specifying their requirements in a new service relationship, than with an established one, a hypothesis supported by recent work in industrial buying behavior for goods (Hutchins, 1992; Landeros \& Monczka 1989). Thus, length of relationship between service provider and customer needs to be considered in an evaluation of participation.

Specific hypotheses developed for an exploratory consideration of the role of participation in services 
marketing are: $\mathbf{H 1}$ Increased customer participation is positively associated with service quality and customer satisfaction, H2 Increased customer participation is associated with positive post-purchase behavioral intentions, $\mathrm{H3}$ Levels of customer participation will be higher in new than in established relationships, and $\mathbf{H 4}$ Post-purchase intentions will be more positive in established than in new relationships.

\section{Method}

In order to reach a preliminary assessment of the value of the participation construct, we sought a suitable research setting. A real-world context was preferred over an experimental design with a convenience sample of MBA students because of a desire to establish the participation construct in a market setting. Because respondent recall raises issues for data reliability we elected to restrict this study to a consideration of professional services because such service events are typically unique and important. An additional study criterion was the opportunity to examine the variables of interest across at least two service settings.

A naturally occurring study opportunity arose among affluent persons creating charitable trusts. Such individuals require the services of a professional service provider who is an expert in the creation of a charitable trust, customarily an attorney or financial adviser. The process of trust creation also involves a second service provider which is the nonprofit beneficiary organization which provides advisory services in connection with the trust. In addition, establishing a charitable trust meets the criterion of importance due to the amount of money involved (an average of $\$ 2.5$ million) and uniqueness (few people establish more than one charitable trust; only $3 \%$ did so in this sample).

This study was based on information provided by 476 individuals who provided information during an extended structured interview designed to collect self-report data about their participation with, resulting attitudes about, and repurchase intentions with respect to two service providers.

\section{Sample}

The study population consisted of all individuals who established charitable trusts in excess of $\$ 1$ million in the U.S. during 1989. The total population size is not known, but is estimated by industry experts to be a few thousand. The sample was obtained from the files of twelve national legal and financial firms that provide advisory services to such individuals. For reasons of practical survey administration, interviewing was restricted to four sites: New York City, Chicago, Los Angeles and Palm Beach. Each respondent was identified and recruited by the relationship manager of the professional firm that had established the trust. This sample is predominantly female $(68 \%)$ as is consistent with other research in philanthropy (Odendahl, 1990). They are generally married $(88 \%)$, highly educated $(84 \%$ hold at least bachelor's degrees), and over 55 years of age $(80 \%)$.

\section{Process}

Twenty-one second-year social science graduate students with prior academic training in field work methods were trained in interviewing with the questionnaire, kept unaware of the ultimate goals of the research, randomly assigned to respondents and closely monitored by one of the authors. The interviews were conducted individually and in-person.

\section{Instrument}

The questionnaire, which had been revised as a result of a pretest with a subset of the population, addressed respondents' motivations for trust establishment and charitable activities, various aspects of the respondents' relationship, participation and future intentions with the nonprofit and the professional service firms that established the trust, and demographics. Most responses were encoded as points on 10-point scales labeled at the end points; e.g., "Not at all True"/"Perfectly True", "Not at all Satisfied"/"Perfectly Satisfied".

\section{Measures}

Participation: Participation was operationalized as one overall variable: "What has been your actual level of involvement --that is, how much time and effort have you invested...?" In retrospect, the choice of the word involvement was questionable, as all respondents may not have focussed to the same extent on the "time and effort", explicitly behavioral, portions of the question.

Attitudes: Satisfaction and perceived quality were each captured as single items: "How would you rate the quality of...?" and "How satisfied were you...?" Satisfaction is customarily captured with a single item. The Servqual scale was evaluated for an assessment of quality but a close examination of the items in that battery showed that they were either inappropriate for professional services or unlikely to produce variation in responses.

Future Behavioral Intentions: The rapidly accumulating literature on customer satisfaction, dissatisfaction, and complaining behavior reveals that consumers display wide variability in their future behavioral intentions with respect to the providers of their goods or services. These intentions vary with respect to valence (positivity or negativity of intentions), and voice (directed towards others or towards the provider). Two comparable 
Table 1

Future Behavioral Intention Batteries and Factor strusture

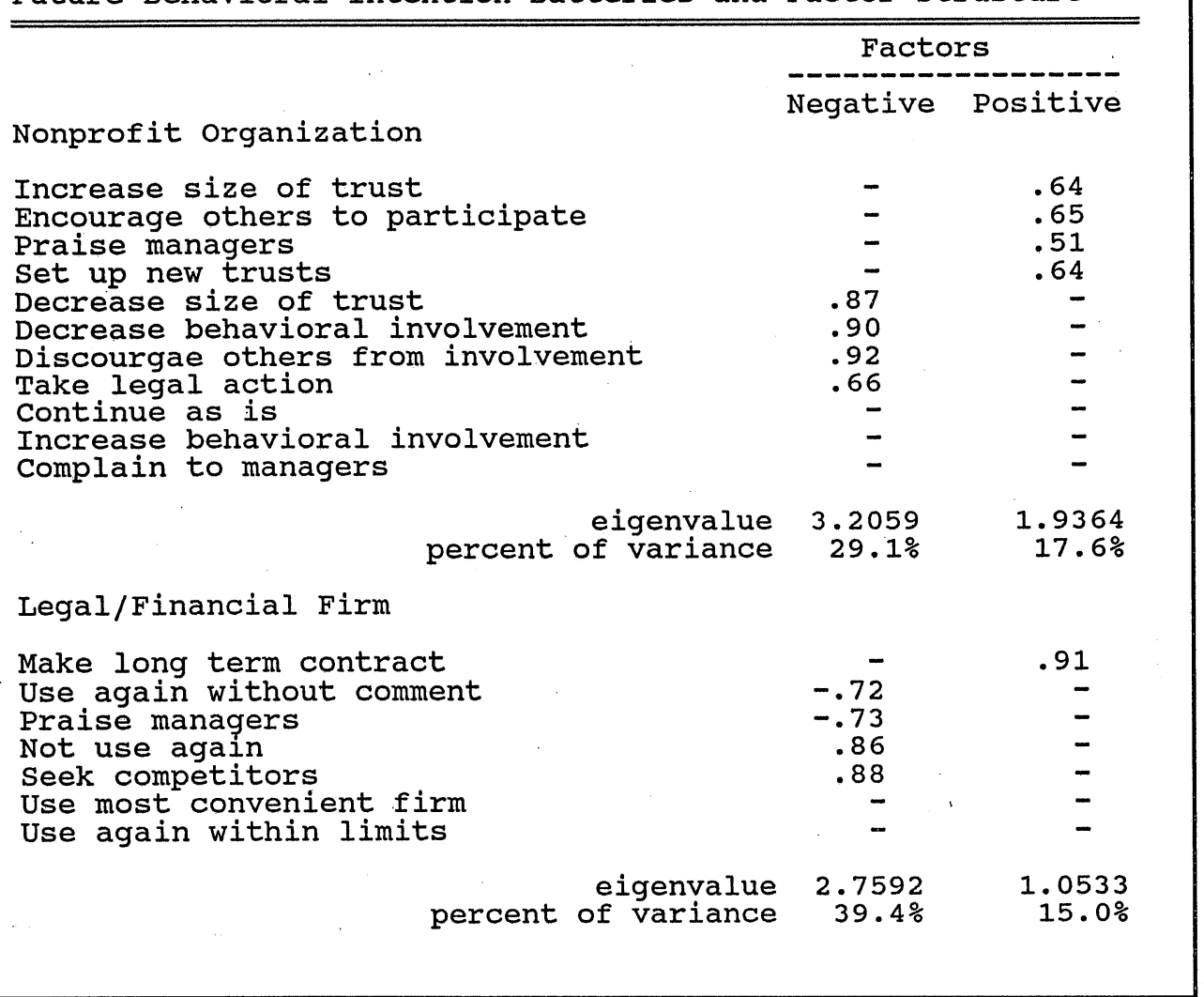

both quality and satisfaction for both nonprofits $(\mathrm{r} 2=.366$ and .181 , $\mathrm{p}<.001)$ and legal/financial firms $(\mathrm{r} 2=.320$ and $.220, \mathrm{p}<.001)$, supporting $\mathrm{H} 1$ that increased participation is associated with increased ratings of quality and feelings of satisfaction among customers.

\section{The Effect of Participation on Future Intentions}

In the interests of simplicity of interpretation, the two batteries of future behavioral intent items were separately subjected to a principal components factor analysis (varimax rotation). The battery of eleven future behavioral intentions with respect to the nonprofit produced four factors, two of which reflect generally positive intent, and generally negative intent. The battery of seven future behavioral intentions with

batteries of items, customized to the service in question, were compiled after a review of the literature on future behavioral intentions. These are listed in Table 1.

Stage of relationship: In the case of the legal or financial services provider, the stage of relationship was defined by whether a prior relationship with the provider had existed prior to the creation of the trust. With nonprofit organizations, the fundamental situation is different: Donors making a major grant invariably have a prior relationship with the organization. In order to maintain comparability, donors were separated into two groups, those whose prior relationship was relatively less developed (as measured by a rating of 5 or below on the level of having previous personal and direct benefit from the nonprofit) and those whose relationship was relatively more developed (a rating of 6 or more on the same scale).

\section{Results}

The Effect of Customer Participation on Perceptions of Quality and Satisfaction

Participation is positively correlated with ratings of respect to the Legal/Financial services provider produced three factors which can be characterized as generally negative, generally positive, and neutral. From each analysis only the positive and negative factors were retained because they were considered comparable measures, and because they reflect the repurchase intentions of interest to practitioners. Table 1 provides a full list of the items in both batteries and the loadings of the positive and negative factors identified for each service.

The effect of participation on future intentions such as repurchase and referral varies across service types. Participation is positively related to future intentions when donors recall their interactions with nonprofits. The more donor participate in interactions with nonprofits, the more likely donors are to have positive future intentions (beta $=.236$, Table 2). On the other hand, in relationships with legal and financial firms, increased participation is associated with increasingly negative intentions toward the provider (beta $=-.175$ ). $\mathrm{H} 2$, the hypothesis that increased participation is associated with positive future intentions, is only partially supported.

The effects of satisfaction and quality on intentions 
toward each provider type are shown in the same table. For both types of service provider, increasing levels of satisfaction and quality are associated with positive intentions, and lower levels of satisfaction and quality are associated with negative intentions, a finding consistent with theory and other research.

analysis of which is beyond the scope of this study.

\section{The Effect of Prior Relationship on Participation}

As discussed previously, stage of relationship (a proxy for the degree of customer experience with the service, or trust in the provider) might also be expected to affect both attitudes and behaviors within the service en-

Table 2

Relationships Between stage of Relationship, Participation, Quality, Satisfaction and Future Intentions by Service

\begin{tabular}{|c|c|c|c|c|}
\hline \multirow[b]{2}{*}{$\begin{array}{l}\text { Stage of } \\
\text { Relationship* }\end{array}$} & \multicolumn{2}{|c|}{$\begin{array}{c}\text { Positive } \\
\text { Intentions } \\
\text { Nonprofit Financial/ } \\
\text { Legal }\end{array}$} & \multicolumn{2}{|c|}{$\begin{array}{c}\text { Negative } \\
\text { Intentions } \\
\text { Nonprofit Financial/ } \\
\text { Legal }\end{array}$} \\
\hline & .193 & - & -.101 & - \\
\hline Participation* & .236 & - & - & .175 \\
\hline Quality* & .126 & .275 & -.379 & -.379 \\
\hline Satisfaction* & .124 & .196 & -.267 & -.236 \\
\hline Adjusted $r 2$ & .066 & .272 & .154 & .319 \\
\hline
\end{tabular}

* Data reported are betas counter as well as future intentions toward the provider. Inspection of the mean ratings by stage of relationship shown in Table 3 indicates that ratings are lower for ongoing relationships on all three variables: satisfaction, quality and participation. H3, the hypothesis that participation levels are higher in new rather than ongoing relationships is supported.

There is an interaction between the type of service and the length of relationship $(F=15.591, \quad d f=6$, $p<.000$ as assessed by a doubly multivariate repeated measures extension of

The Effect of Type of Service on Associations Between Participation and Repurchase

The analysis shows significant differences in the mean levels of participation, satisfaction, and quality by service type. Inspection of the means and standard errors shown at the top of Table 3 makes it clear that satisfaction and quality are rated lower for legal/financial services (6.24 and 6.86) than for nonprofits (8.19 and 9.07). Level of participation is also lower for legal/financial services (3.04 as compared to 6.45 for nonprofits). This finding demonstrates that the participation level of customers varies across services.

This difference between service types in buyers' future intentions toward the provider even with degree of satisfaction, perceived quality, and participation taken into account through the use of a doubly multivariate repeated measures extension of multiple analysis of variance $(\mathrm{F}=56.721, \mathrm{df}=5, \mathrm{p}<.000)$. Thus, as with participation and attitudes, customers' future behavioral intentions differ across services. This variance may arise from structural characteristics of the service itself, customer attitudes behaviors specific to certain services, to differential customer management by the service provider or to a combination of all these effects, an multiple analysis of variance). Hypothesis 4 receives partial support. In the case of nonprofits, hypothesis 4 is supported in that ratings of quality and satisfaction are higher for more developed relationships as compared to less developed ones. In the case of legal and financial service providers there is no support for the hypothesis: ratings of quality and satisfaction are higher in new relationships.

Results do provide consistent support for the effect of stage of the relationship on buyers' future intentions including repurchase and referral $(\mathrm{F}=3.97, \mathrm{df}=6$, $\mathrm{p}<.001$ ), and support relationship marketing paradigms. New relationships are associated with greater negative and smaller positive intentions, while established relationships are associated with smaller negative and greater positive intentions. Again, there is variation across services in degree rather than direction; this effect is particularly pronounced with legal and financial firms.

\section{Conclusions}

Participation has been shown to be associated with quality, satisfaction and future intentions towards service providers. However, the inconsistency of the effect of participation across services implies that additional work 
Table 3

Means and Standard Errors for Participation, Quality and Satisfaction by Service Type and Stage of Relationship

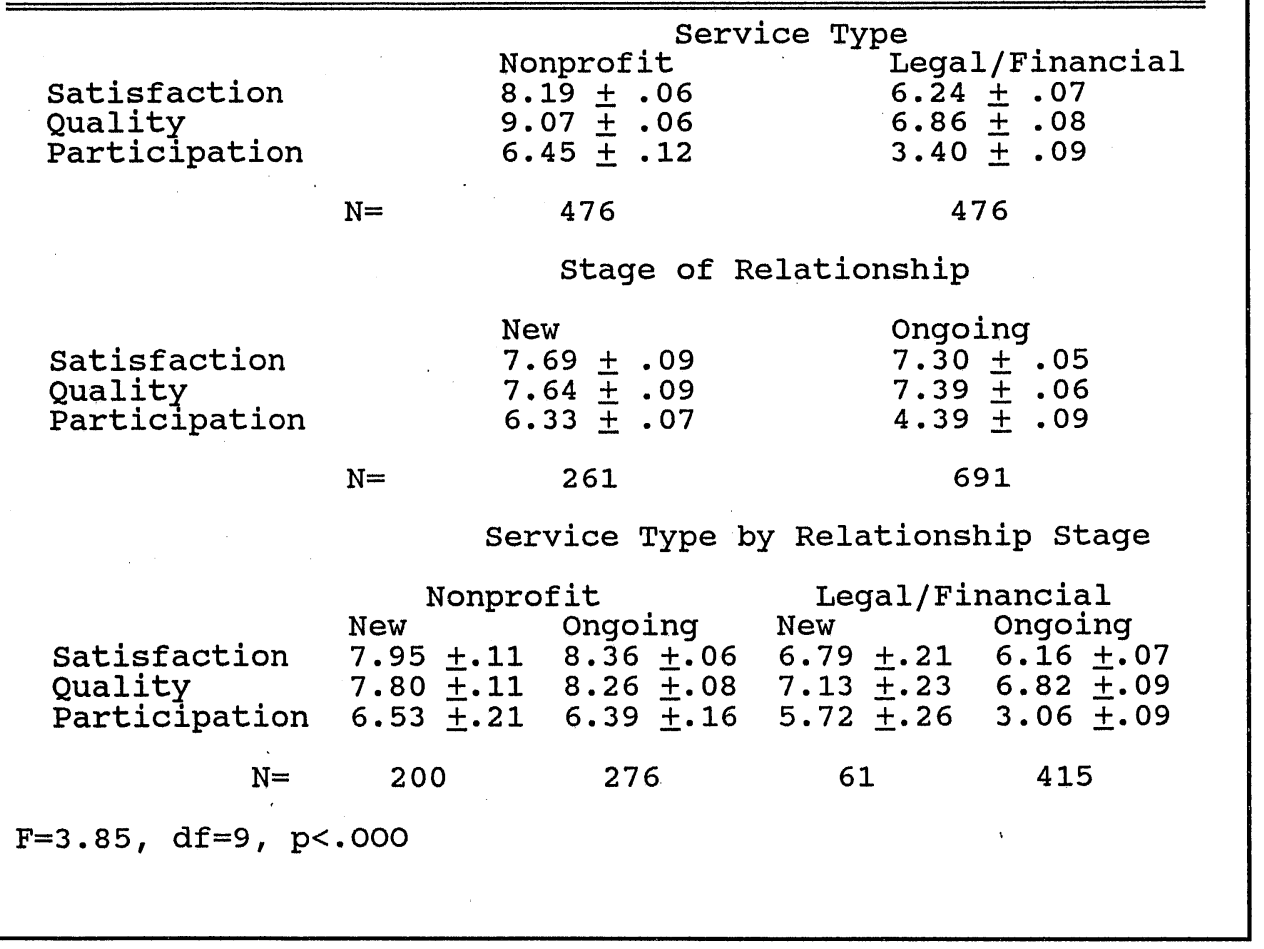

Implications for Practitioners

From a practitioner standpoint, these conclusions raise several issues regarding the strategy of stimulating consumer participation in service processes. They suggest that buyer participation has a measurable effect on the desired future behaviors of repatronage, but that the effect is situation specific. In some service settings stimulating greater participation by buyers has positive consequences for the provider whereas in other service situations it has negative consequences. More specific examination of the conditions under which greater or lesser buyer participation is to be sought is clearly important to productive service management. evaluating this construct empirically will be required. Of the four hypotheses advanced for this research, two were supported in both services examined. Increased customer participation is found to be positively associated with service quality and customer satisfaction. In addition, levels of customer participation are higher in new than in established relationships. However, two hypotheses received only partial support in this study. Increased customer participation is associated with positive postpurchase behavioral intentions for one of the two services studied. And in one of the two services were post-purchase intentions found to be more positive in ongoing than in new relationships.

This research confirms propositions emanating from the services marketing literature that the participation of consumers in the specification and delivery of services should be associated with subsequent attitudes and behaviors. These results add support to maintaining the distinction between attitudes and behaviors distinction and would favor restricting the use of the term "involvement" to mean a state or attitude and the term "participation" to refer to actual behavioral involvement. The inclusion of a measure of participation in the study of service transactions clearly contributes to our understanding of future behavioral intentions toward the provider.

\section{Suggestions for Future Research}

These findings support the continued exploration of the utility of the participation construct. That exploration should proceed in several areas. One possibility to explore is that the relationship between participation and future intentions may be an inverse one in certain high-end professional service settings; that is, customers may feel that high degrees of participation may be associated with poor service and the need to intervene to correct problems in the service transaction itself. A useful next step will be the creation of a participation scale and exploration of the relative roles of participation intensity and the effect of different forms of participation (e.g. impersonal; face-to- face). The observed differences in the role of participation in different service settings needs to be attributed to structural, consumer psychological or other factors in the service encounter.

\section{*\%* References\%*\%}

1. Allport, G. W. "Attitudes" in C. Murchinson (Ed.) Handbook of Social Psychology, Clark University Press, Worcester, MA, 1935.

2. Bagozzi, R.P. "Marketing as Exchange," Journal of Marketing, Vol. 39, October, pp. 32-39, 1975. 
3. Bandura, A. Principles of Behavior Modification, Holt, Rinehart and Winston, New York, NY, 1976.

4. Bateson, J.E.G. "Perceived Control and the Service Encounter," in J.A. Czepiel, C.A. Suprenant and M.R. Solomon (Eds.), The Service Encounter: Managing Employee/Customer Interaction in Service Businesses, Lexington Books, Lexington, MA, pp. 68-72, 1985.

5. Batra R. \& Ray, M.L. "Operationalizing Involvement as Depth and Quality of Cognitive Response," in Advances in Consumer Research, Vol. 10, Association for Consumer Research, Ann Arbor, MI, pp. 309-313, 1983.

6. Beatty, S.E., Kahle, L.R. \& Homer, P. "The Involvement- Commitment Model: Theory and Implications." Journal of Business Research, Vol. 16, No. 2, pp. 149-167, 1988.

7. Bentler, P.M. \& Speckart, G. (1981). "Attitudes "cause' behaviors: A structural equation analysis." Journal of Personality and Social Psychology, 40(2), 226-238.

8. Bloch, P.H. "An Exploration into the Scaling of Consumers' Involvement with a Product Class," in Advances in Consumer Research, Vol. 8, Association for Consumer Research, Ann Arbor, MI, pp. 61-65, 1981.

9. Cermak, D.S. P., File, K.M. \& Prince, R.A., "Complaining and Praising in Non-Profit Exchanges: When Satisfaction Matters Less," Journal of Consumer Satisfaction, Dissatisfaction and Complaining Behavior, pp. 180-187, 1991.

10. Chase, R.B. "Where Does the Customer Fit in Service Operations?" Harvard Business Review, Vol. Nov/Dec, pp. 137- 142, 1978.

11. Clarke, K. \& Belk, R.W. "The Effects of Product Involvement and Task Definition on Anticipated Consumer Effort," in Advances in Consumer Research, Vol. 6, Association for Consumer Research, Ann Arbor, MI, pp. 313-318, 1979.

12. Czepiel, J.A. "Service Encounters and Service Relationships: Implications for Research," Journal of Business Research, Vol. 20, pp. 13-21, 1990.

13. Day, G.S. Buyer Attitudes and Brand Choice, Free Press, New York, 1970.

14. Engel, J.F. \& Blackwell, R.D. Consumer Behavior, Dryden Press, New York, 1982.

15. Fazio, R.H. \& Zanna, M.P. "Direct Experience and Attitude- Behavior Consistency." Advances in Experimental Social Psychology, Vol. 14, pp. 161-202, 1981.

16. Festinger, L. A Theory of Cognitive Dissonance, Row, Peterson, Evanston, Il, 1957.

17. Greenwald, A.G. \& Leavitt, C. "Cognitive Theory and Audience Involvement," in L. Alwitt \& A. Mitchell (eds.) Psychological processes and advertising effects, Lawrence Erlbaum, Hilldale, NJ, pp. 221-240, 1985.

18. Higie, R.A. \& Feick, L.F. "Enduring Involvement: Conceptual and Measurement Issues," Advances in
Consumer Research, Vol. 16, Association for Consumer Research, pp. 690-696, 1989.

19. Houston, M.J. \& Rothschild, M.L. "Conceptual and Methodological Perspectives on Involvement," in Educator's Proceedings (Ed.) S.C.Jain, American Marketing Association, Chicago, Il, pp. 184-187, 1978.

20. Hutchins, G. The Purchasing Strategies for Total Quality: A Guide to Achieving Continual Improvement, Business One Irwin, Homewood, Il, 1991.

21. Kelley, S.W., Donnelly, J.H.Jr., and Skinner, S.J. "Customer Participation in Service Production and Delivery," Journal of Retailing, Vol. 66, pp. 315335, 1990.

22. Kelman, H.C. "Attitudes are Alive and Well and Gainfully Employed in the Sphere of Action." American Psychologist, Vol. 29, pp. 310-324, 1974.

23. Landeros, R. \& Monczka, R.M. "Cooperative Buyer/Seller Relationships and a Firm's Competitive Position." Journal of Purchasing and Materials Management, Vol. Fall, pp. 9-18, 1989.

24. Lastiovicka, J.L. \& Gardner, D.M. "Components of Involvement" in Attitude Research Plays for High Stakes (Eds.) Maloney, J.C. \& Silverman, B. American Marketing Association, Chicago, IL, pp. 53-73, 1979.

25. Laurent, G. \& Kapferer, J.N. "Measuring Consumer Involvement Profiles," Journal of Marketing Research, Vol. 22, pp, 41- 53, 1985.

26. Lovelock, C.H. \& Young, R.F. "Look to Customers to Increase Productivity." Harvard Business Review, Vol. May/June, pp. 168-178, 1979.

27. McGuire, W.J. "The Concept of Attitudes and Their Relation to Behaviors," in H.W. Sinaiko and L.A. Broedling (Eds.). Perspectives on attitude assessment: Surveys and their Alternatives, Pendleton, Champaign, IL, 1976.

28. Mills, P.K. and Moburg, D.J. "Perspectives on the Technology of Service Operations," Academy of Management Review, Vol. 7, pp. 467-478, 1982.

29. Mills, P.K. and Morris, J.H. "Clients as "Partial" Employees of Service Organizations: Role Development in Client Participation." Academy of Management Review, Vol. 11, pp. 726-735, 1986.

30. Mitchell, A.A. "Involvement: A Potentially Important Mediator of Consumer Behavior. in Advances in Consumer Research, Vol 6, Association for Consumer Research, pp. 191-196, 1979.

31. Odendahl, T., Charity Begins at Home: Generosity and Self-Interest Among the Philanthropic Elite, Basic Books, New York, 1990.

32. Petty, R.E., Cacioppo, J. T. \& Schumann, D. "Central and Peripheral Routes to Advertising Effectiveness: the Moderating Role of Involvement." Journal of Consumer Research, Vol. 10, September, pp. 135-146, 1983.

33. Pucely, M.J., Mizerski, R. \& Perrewe, P. "A Comparison of Involvement Measures for the Purchase 
and Consumption of Pre- recorded music," Advances in Consumer Research, Vol. 15, Association for Consumer Research, Ann Arbor, MI, pp. 37-42, 1988.

34. Ram, S. \& Jung, H.S. "The Link Between Involvement, Use Innovativeness and Product Usage," Advances in Consumer Research, Vol. 16, Association for Consumer Research, Ann Arbor, pp. 160-166, 1989.

35. Ray, M.L. "Marketing Communications and the Hierarchy of Effects," in P. Clarke (Ed.) New Models for Mass Communication Research, Sage Publications, Beverley Hills, CA, pp. 147-176, 1973.

36. Richins, M.L. \& Bloch, P.H. "After the New Wears Off: The Temporal Context of Product Involvement," Journal of Consumer Research, Vol. 13, September, pp. 280-285, 1986.

37. Richins, M.L. \& Root-Shaffer, T. "The Role of Involvement and Opinion Leadership in Consumer Word-of-Mouth: An Implicit Model Made Explicit," Advances in Consumer Research, Vol. 15, Association for Consumer Research, Ann Arbor, MI, pp. 32- 36, 1988.

38. Richins, M.L. \& Bloch, P.H. "Post-Purchase Product Satisfaction: Incorporating the Effects of Involvement and Time. Journal of Business Research, Vol. 23, pp. 145-158, 1991.

39. Sherif, M. \& Cantril, H. The Psychology of Ego Involvement, Wiley, New York, 1947.

40. Slama, M.E. \& Tashchian, A. "Selected Socioeconomic and Demographic Characteristics Associated with Purchasing Involvement," Journal of Marketing, Vol. 49, winter, pp. 72- 82, 1985.

41. Traylor, M.B. \& Joseph, W.B. "Measuring Consumer Involvement in Products: Developing a General Scale." Psychology and Marketing, Vol. 1, No. 2, pp. 65-77, 1984.

42. Wicker, A.W. "Attitudes Versus Actions: The Relationship of Verbal and Overt Behavioral Responses to Attitude Objects," Journal of Social Issues, Vol. 25, pp. 41-78, 1969.

43. Zaichkowsky, J.L. "Familiarity: Product Use, Involvement or Expertise?" in Advances in Consumer Research, Vol. 12, Association for Consumer Research, Ann Arbor, MI, pp. 296- 299, 1985 a.

44. Zaichkowsky, J.L. "Measuring the Involvement Construct," Journal of Consumer Research, Vol. 12, December, pp. 341-352, 1985b.

45. Zeithaml, V. "How Consumer Evaluation Processes Differ Between Goods and Services," in J.H. Donnelly and W.R. George (Eds.), Marketing of Services, American Marketing Association, Chicago, Il, pp. 186-190, 1981. 